\title{
FORMATION OF FUTURE SERVICE SECTOR \\ SPECIALISTS' COMMUNICATIVE CULTURE \\ DURING PROFESSIONAL TRAINING
}

\section{Rudenko Larisa ${ }^{1}$ \\ Lytvyn Andriy ${ }^{2}$}

DOI: http://dx.doi.org/10.30525/978-9934-571-27-5_43

\begin{abstract}
The purpose of the research is to determine the theoretical and methodological principles of forming the communicative culture of future service sector specialists at the vocational school as a didactic system, which ensures the improvement of the quality of training of skilled workers for this sector in the innovative educational environment. On the basis of the scientific and methodological analysis of the concept of person's communicative culture, taking into account the peculiarities of professional activity of the service sector workers, as well as the directions of the vocational education modernization, the authors proposes the ways to form future service specialists' communicative culture as a means of personal and professional growth, and the professional competence improvement. Based on the application of complex methodological approaches and general pedagogical laws and principles of learning, the authors define the regularities, specific principles, and pedagogical conditions for forming service sector specialists' communicative culture, as well as justify, develop, and experimentally test the model of formation of service sector specialists' communicative culture while training, that allow vocational institutions preparing workers for service sector to provide training to meet the requirements of the so-ciety to the levels of service, and enhance the competitiveness of their graduates. In order to ensure the integrity and dynamics of the structure of service sector specialists' communicative culture the authors distinguish person-reflexive, epistemological-cognitive, operational-technological and professional-adaptive components, which requires psychological and edu-
\end{abstract}

\footnotetext{
${ }^{1}$ Doctor of Pedagogical Sciences, Senior Researcher,

Professor at Department of Practical Psychology and Pedagogy,

Lviv State University of Life Safety, Ukraine

${ }^{2}$ Doctor of Pedagogical Sciences, Professor,

Head at Department of Practical Psychology and Pedagogy,

Lviv State University of Life Safety, Ukraine
} 
cational activities for its formation. This includes the design and implementation of the integrated method of future service sector specialists' communicative culture formation that is able not only to provide students with professionally significant communicative knowledge, skills and abilities, but also to promote their creative personal development and to increase their capacity to adapt and self-realize in professional activities. It is proved that the use of the authors' system of communicative culture formation in vocational training, especially the intro-duction of "Fundamentals of service sector specialists' communicative culture" special course and methods of service sector specialists' communicative culture formation, promotes the creative personal, professional and communicative development of vocational school students, and improves the efficiency of the educational process and pedagogical interaction.

\section{Introduction}

New socio-economic realities, the entry of Ukraine into the World Trade Organization and the desire to join the European Community cause changes in the educational system that ensure reproduction of the intellectual and spiritual potential of the state, the rise of the social and productive sphere, the establishment of the principles of democracy, the sustainable development, and the quality of life. The purpose of vocational education is to prepare competitive staff with a proper social and cultural level for various sectors of economy, production and service.

Nowadays public needs stimulate the active growth of quantitative and qualitative dimensions of the service sector, the demand and the requirements for its quality are increasing. It requires that service sector specialists possess not only proper competence but also a high culture of service, which determines the task of vocational schools of the corresponding profile.

The professional competence of a specialist definitely implies the possession of professional knowledge, skills and abilities, among which a significant place belongs to the knowledge of norms and rules of interpersonal interaction, communication skills, adequate reporting of information, and reflection of own professional activities. The formation and development of the professional competence of a service sector specialist is connected, first of all, with the formation of communicative culture, which reflects not only the perfect command of the language on the verbal and nonverbal levels, but also the ability to communicate, adhering to moral and ethical norms 
and taking into account the psychological peculiarities of the interlocutor. The communicative activity of service professionals is of an interpersonal character and provides their socially acceptable behavior during interpersonal interaction. In economically developed countries, this is the main criterion for employment and career growth for "man-man" professions. Taking it into account, the communicative culture should be considered as one of the main components of the professional competence of the service sector specialists.

Some aspects of the problem of communication, formation of the interpersonal interaction style, and the communicative culture of different specialists are covered in numerous publications, however, the task to form service sector specialists' communicative culture while training remains poorly researched.

\section{Research methodology}

The methodological basis of the research is the following: dialectic statement on the transition of quantitative changes into qualitative new formations of a personality, the active participation of the subject in cognitive activity, the activity as a way of self-realization of a person while working and communicating; hermeneutic theory of inter-subjective understanding as an adequate comprehension of the subjectivity of another person and recognition of a sovereign human personality; cultural and axiological theories of self-actualization of a personality; psychological and pedagogical theories of axiological, person-oriented, activity and competence approaches to the training of skilled workers, the development and self-development of personality's professional qualities.

The leading idea of the study is that the formation of a communicative culture of future service sector professionals while studying at a vocational school is a priority direction for the formation and development of their professional competence, based on the psychological and pedagogical theory and practice and oriented on the subject-subject relations in educational and work activities. This direction is consistently implemented in the process of education and production activities by mastering the necessary knowledge, acquiring skills, gradually improving the personal and business communicative qualities and accumulating the experience of communicative interaction. The concept of the research is based on the consideration of communicative culture as an important component of the general culture 


\section{Formation of future service sector specialists' communicative culture during...}

and professional competence of the individual, an essential element and characteristic of the production activity of service sector specialists, and determines the theoretical and methodological principles of forming the communicative culture of future specialists while training. It is based on the following provisions:

1. The transition to the information society is accompanied by the aspirations of humanity to spirituality, culture, and comprehension of universal, interpersonal and professional values, which actualizes the growth of the role of a complex social phenomenon of communication. Cultural and communicative basis of social life are interpersonal relationships realized in the process of communication, which promote the unity of views, mutual understanding and coherence in personal life and work and are formed during education and training.

2. Social changes are progressive only if they stimulate the development of society members, each person is considered from the point of view of anthropocentrism, and the satisfaction of everyone's needs is the main goal of all the reforms. In this regard, vocational education in accordance with the cultural, synergetic and personally oriented educational paradigm requires the search for new approaches to the training of specialists in order to form and develop a holistic creative free personality capable of socialization, adaptation and self-realization in the society. The nature of innovation should take into consideration the specifics of the level and profile of vocational education, and reflect the social requirements for the specialists' training and the students' needs.

3. The strategic task of VET is to train young people in accordance with the needs of modern and future labor markets. Professional training is a period of initial personal identification of a specialist, formation and development of professional competence, mastering of professional knowledge, production skills and abilities, acquisition of educational and professional qualifications and formation of psychological readiness for the future profession and planning of social and professional development. It should be guided by the requirements of the best enterprises, the development of the students' qualities that meet the perspective needs of the industry and guarantee the graduates the competitiveness of the qualifications.

4. According to the new paradigm of education, the educational process at a vocational school should be aimed at training of specialists who possess a sufficient amount of theoretical knowledge and practical skills; have 
advanced socially and professionally important qualities that enable them to successfully adapt to future activities and self-improvement. This implies the education of the individual with a proper communicative culture that will provide a socially acceptable level of interpersonal relationships in the professional sphere, the mastering of the basic professional roles, forms of communication necessary for the successful work, the formation of professional reflection and students' self-awareness.

5. Solving the problem of the communicative culture of service sector professionals requires the creation of a didactic system based on functional responsibilities and modern features of professional activity in the industry. This will allow forming their communicative culture as a component of professional competence: to develop socially and professionally important qualities, to develop skills of constructive communication at all the stages of service, skills of establishing contacts in the professional sphere taking into account age, status and socio-cultural characteristics, application of feedback and presentation of the service, productive dialogue with verbal and nonverbal means of communication, etc.

The training of future service sector specialists at vocational schools requires adjusting the goal, updating the content, improving the educational technology, bringing the tasks of vocational and communicative training in line with the requirements of the new educational paradigm for the formation of a communicative culture that determines the competitiveness of vocational school graduates in the labor market. To do this it is necessary: to substantiate the pedagogical conditions of the formation of service sector specialists' communicative culture at vocational school, to determine the ways of implementing modern pedagogical technologies in this process, to use the potential of general education, general professional, theoretical and practical training in order to develop of students' communicative culture, to prepare teachers for the formation of students' communicative culture, which will enable to prepare students for their professional activities according to the State standards of professional education and industry requirements.

\section{The theoretical foundations of the research}

Retrospective study of the development of the service sector (Rudenko L. A. \& Lytvyn A. V., 2015) revealed that the transition from the production of goods to the production of services in the 40-s and 50-s of the $19^{\text {th }}$ century 


\section{Formation of future service sector specialists' communicative culture during...}

determined the need to organize educational institutions for training such specialists. Nowadays, their training takes place in the system of VET as a complex of pedagogical, organizational and managerial measures aimed at students' mastering knowledge, skills and abilities in the chosen field of professional activity, the development of competence and professionalism, general culture and professional competence. The growth of the importance of the sphere of services in the modern society caused the necessity of its study in the scientific, social sciences and professional aspects. The service sector as a special type of human activity, aimed at satisfying the needs of the client through the provision of services, is the subject of service study (Ananieva T. N., But-kevich M. N., \& Baghdasarian V. E., 2008). The analysis of its main principles shows that services are positioned through communication in the process of joint activity of a service sector specialist and client (Udaltsova. M. V. \& Averchenk L. K., 2002).

The study of work specifics of services sector specialists in revealed that their professional functions are implemented in the professional communication activities, which involves the impact on the interlocutor during the direct interaction, cooperation, dialogue, coordination and requires the ability to find constructive communication strategies, to perceive the interlocutor consciously.

The communicative culture of service sector specialists is an integrated characteristic of the individual as a subject of professional activity, which ensures the implementation of professional competence in communicative activities while providing services and at the same time contributes to personal and professional growth. It has common cultural features and is manifested in the inner personal culture; predetermined by the development and self-development of a person and manifested in the creative nature of mastering the best examples of communicative activity; is ensured by orderliness of knowledge, norms, values and patterns of behavior accepted in the society, their organic implementation in professional activities; is based on the ability to easily establish contacts during communication, to show flexibility, psychological and professional tact, emotional stability, to possess verbal and non-verbal means of communication and language ethic; promotes professional adaptation and self-actualization of the individual.

The analysis of the problem of communicative culture and its formation by future service sector specialists in the pedagogical theory and practice makes it possible to determine methodological approaches to solve 
the above-mentioned problem, namely: cultural, axiological, person-oriented, synergetic, activity and competence ones. According to the cultural approach, the communicative culture of a service sector specialist is a professional and personal quality, the essence of which reflects the general culture of the personality and influences the effectiveness of professional activity. The implementation of the axiological approach involves influencing the formation of the communicative qualities of future service sector professionals as a professionally valuable, mastery of which will ensure the transformation from personally significant qualities to professionally significant ones. The application of the person-oriented approach is directed at the development of the motives for self-realization, the disclosure of students' personal potential, the establishment of subject-subject relations as a model of the future communicative culture. The synergetic approach for the professional training of future service sector specialists as a special form of their self-development will promote students' professional and personal growth, the awareness of the need for professional self-development, self-education and self-improvement. The activity approach allows us to understand the communicative culture as an instrument of successful professional activity, the precondition for self-realization and encourages using active methods of forming a communicative culture, practical skills of communicative interaction while providing services. The competent approach for the development of the communicative culture of future service sector professionals involves the formation of their communicative competence, which essence is to master the theoretical knowledge, ethical and psychological provisions, principles and norms that are common in a certain professional community, as well as the formation of skills for performing definite communicative tasks in real production situations, finding solutions to the difficulties encountered during communication while working. On this basis, the authors' suggestions regarding the formation of service sector specialists' communicative culture while training at vocational school were drawn up.

The application of the above-mentioned set of methodological approaches to ensure the integrity and dynamism of the communicative culture of service sector professionals allows distinguishing the following components in it: person-reflexive, epistemological-cognitive, operational-technological and professional-adaptive ones (Rudenko L, 2012). Person-reflexive component is based on the structure of a personality as a subject of interpersonal 


\section{Formation of future service sector specialists' communicative culture during...}

relations, manifested in the general culture, humanistic and communicative orientation of the individual, characterized by a person's ability to reconcile and correlate his/her actions with others, acceptance of another, understanding and respect for other thoughts, readiness to tactful communicative interaction and reflection in communicative activity (Rudenko L., 2013, p. 90). It combines the motivational-value, person-communicative and communicative-reflexive competencies that envisage the impact on future specialists' development of motivation to improve their own communicative culture, self-education and self-improvement and the formation of a stable desire for professional interaction on the basis of mutual perception. The epistemological-cognitive component is aimed at the development of cognitive abilities of the individual, his/her ability to effectively perceive and comprehend information, to assess the communicative situation adequately, and it influences the transformation of professional knowledge into the system of own judgments, views and behavior (Rudenko L., 2014a). Gnostic, mental and perceptual competences of this component involve the formation of a specialist's com-municative consciousness, the development of perceptual ability, taking into account the peculiarities of communicative interaction on the basis of background knowledge.

The operational and technological component of communicative culture is connected with a complex of communicative skills that provide an effective course of communicative processes in professional activity and is a system of internal means of regulating communicative actions. It includes lingua-communicative, connective-operational and informational and technological competencies reflecting the readiness of vocational school graduates to carry out their professional activities on the basis of the practical application of communicative skills, the selection of professionally relevant information, including the use of electronic telecommunication facilities (Rudenko L., 2014b). The professional and adaptive component of the communicative culture of service sector specialists is manifested in the peculiarities of a vocational school graduateentering labor collective and is an indicator of the effective performance of their professional communication functions (Rudenko L., 2016). It consists of the socially adaptive, status-role competence and the competence of self-presentation, which reflect the tendency of a service sector specialist for professional self-assertion, achievement of specific goals in communicative interaction and his/her professional-role multiplicity. 
The patterns of the formation of the communicative culture of service sector specialists are formulated. The first pattern is based on the understanding of communicative culture as a social and individual-personal phenomenon connected with the formation of the social and individual consciousness and that is its spiritual component, conditioned by the humanistic requirements of the social development. In accordance with the second pattern, the competitiveness of a service sector specialist is determined by the level of development of his/her communicative culture in its personal and professional values. The third pattern is that the process of forming a communicative culture of future service sector specialists at vocational schools belongs to the cognitive and transformative activity that results from the pedagogical impact; is based on a personality's certain qualities; aimed at ensuring person's self-development on the axiological and humanistic principles. The fourth pattern reflects the purposefulness of the development of the communicative culture of the future service sector specialist as his/her integral professional and personal characteristics, expressed in the unity of personality-reflexive, epistemological-cognitive, operational-technological and professionally-adaptive components. These patterns allowed the authors to determine the specific principles to form the communicative culture of service sector specialists (Rudenko L., 2015, pp. 163-164, 174-180). The principle of cultural correspondence of a personality's professional development is oriented on the cultural ideas of nowadays that are reflected in the contents, methods and results of the educational process at vocational schools, where in the center there is a future specialist as an active person, capable of self-determination in professional communication and interaction with other people, of internal and external culture harmony. The principle of humanization and humanization of vocational and communicative training on an axiological basis should ensure a person's development on a value basis, person's orientation in the world of human values. This principle manifests itself in the influence on the formation of students' communicative culture through the development of their own system of professional and personal values, value attitude to the content and results of training and future professional activities, professional roles and positions. The principle of student's subjectivity in teaching, production and professional activities means the recognition and awareness of student's unique personality, self-worth, and development as an individual with a unique subject experience, a combination of mental and cultural fea- 
tures. In the context of the formation of a communicative culture of service sector specialists, this principle involves the personality's self-realization through communication. The principle of a personality's self-development while communicating makes it possible to get a student interested in the need for self-changes, motivating his/her further professional development. Its pedagogical impact results in high motivation of production activities, faster adaptation in production and successful career development, availability of the best psychological characteristics according to communicative parameters. Thus, a student self-asserts as a person, grows professionally and self-organizes. The principle of consciousness and activity unity in communicative interaction declares their belonging to the conscious and active subject. Activity affects the formation of consciousness, psychic relationships, processes, personality traits, and they regulate person's activities and are a condition of person's adequacy. The communicative culture of service sector specialists reflects both their personal characteristics and the specific nature of their professional activities. The principle of the integrity of a specialist's communicative functions reflects the whole complex of tasks necessary to resolve in professional activities. The ultimate goal of professional training of service sector specialists is their professional identification, which must be ensured by professional competence.To perform professional activities successfully and to develop professional reflection and professional self-awareness, students need to master knowledge about the peculiarities of the profession, the main professional roles and forms of communication in the service process, which will ensure the filling of communicative interaction with professional content. Accounting for these patterns and principles allowed the authors to substantiate the pedagogical conditions for the formation of a communicative culture of service sector specialists:

- orientation of the process of communicative culture formation to the devel-opment of the personality of future service sector specialists is ensured by the students' reflexive attitude towards the professional activity and its communicative component; by the awareness of the importance of communicative culture for professional activities based on high motivation and value orientations; by the need for the development of professional and communicative qualities, the desire for professional and personal growth; by the involvement of students into communicative activity in order to develop their professional and communicative qualities; by the stimulation 
of their personal and professional autonomy and creative abilities in order to provide reflexive analysis of their own communicative possibilities;

- the introduction of "Fundamentals of the service sector specialists' commu-nicative culture" special course provides for the direction of its content to the for-mation of the communicative consciousness of the individual, the improvement of communicative competences that will determine the specialist's communicative actions and coordinate the system of his/her communicative values; the consolidation of the moral and ethical principles of interpersonal interaction; the communicative knowledge, practical skills of performing professional duties in a real production process based on their internalization while training; the organization of person-oriented interaction of subjects of the educational process to enrich and systematize professional and communicative values and knowledge of vocational school students;

- the development and application of a holistic methodology to form service sector specialists' communicative culture at vocational school - the development of the system of internal means of communicative action regulation; the formation of the skills of communicative behavior in professional activity, the knowledge of special computer programs used in service sector by combining traditional and innovative pedagogical technologies; giving the students wide opportunities for creative use of acquired competencies in real and simulated production communication situations;

- the purposeful inclusion of communicative competences into the educational and production activities of future service sector specialists - the activation of vocational and communicative interaction in the process of production training; future specialists' self-realization in the educational dialogue; the exact use of acquired communicative competences in real production situations during practice in service sector; the increase of students' adaptive qualities.

The implementation of these pedagogical conditions is aimed at forming the vocational school students' communicative culture, their attitude to it as a factor of successful professional activity, their awareness of the possibility of professional self-improvement through its development, their readiness for future professional activity taking into account the society demands for the service sector.

To study comprehensively and to observe the development of the research process the authors work out the dynamic model of the system of formation of the service sector specialists' communicative culture (Fig. 1), 


\section{Formation of future service sector specialists' communicative culture during...}

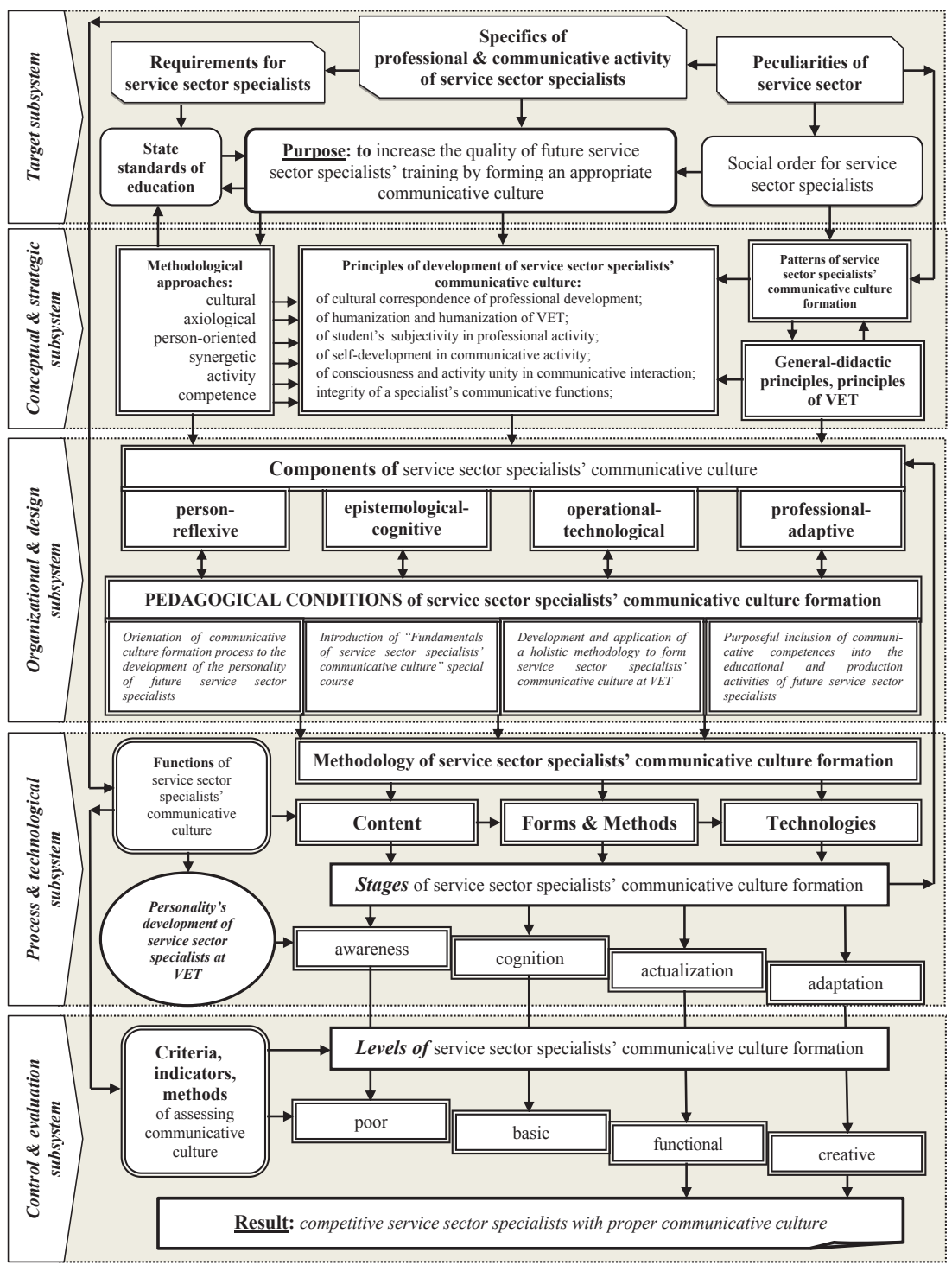

Fig. 1. Model of the system of forming service sector specialists' communicative culture 
consisting of several subsystems. The target subsystem is based on a social order for highly skilled service sector specialists. Its central part is to increase the quality of future service sector specialists' training by forming an appropriate communicative culture, which is conditioned by the specifics of the industry, the peculiarities of the professional and communicative activities of specialists in the service sector, and is based on the requirements reflected in the State standards of VET. The organizational-design subsystem covers the structure of the communicative culture of the service sector specialists and the pedagogical conditions for implementing the model which reflect the resources and the leading factors of this process organization, their influence on the interaction of elements of the system of forming the communicative culture of vocational school students.

The process-technological subsystem contains the methodology of formation of service sector specialists' communicative culture (the content, forms, methods, technologies, stages of formation of specialists' communicative culture), developed taking into account the functions of communicative culture, which are: in optimizing the personality's formation in a particular community; in reflecting the person's positions as for the needs in interaction; in determining the level of success and effectiveness of service sector; in promoting a specialist's personal and professional growth; and in realizing a specialist's professional competence while working. The control and evaluation subsystem is connected with the creation of a diagnostic apparatus, which allows determining the level of communicative culture of vocational school leavers, includes the criteria, indicators and methods for assessing the levels of its development, as well as the expected results of implementing the model. The model is worked out taking into account the analysis of the professional and communicative activities of service sector specialists and the predictions of its development.

The formation of a communicative culture of future services sector specialists requires the development of the methodology that can provide students with professionally meaningful communicative knowledge, skills and abilities, promote their creative personal development and increase their opportunities for adaptation and self-realization in professional activities. Accordingly, the methodical principles of forming the communicative culture of future service sector specialists, reflected in the process-technological subsystem, are based on the implementation of the permanent systemic pedagogical impact on the formation of all its components. The content part 
of the methodology is determined by the requirements of the State standards of VET, reflected in the educational and qualification characteristics of service sector specialists. Its introduction implies the expediency, systematic, gradual and phased organization of the process of forming service sector specialists' communicative culture as a personality's holistic characteristics, manifested in the readiness to use acquired communicative competences in future professional activities. The methodology involves the participation of all the teaching staff in the communicative develop-ment of vocational school students for the purpose of daily training in learning and production vocational and communicative activities led by teachers.

Among the methods of forming the communicative culture of future service sector specialists, particular attention is paid to interactive ones, since they allow positioning the student as a subject of learning, who deepens his/her communicative potential while doing creative tasks, solving problem situations, etc. We choose the due to the possibility of using visual and audio channels of information perception, the development of professional communication skills on the basis of mental activities activation, the formation of communicative skills based on the personality's creative traits in professional activity.

Taking into account the structural components, tasks and pedagogical conditions of communicative culture formation, there are four stages of this process in order to trace the internal relations of the structural components of the communicative culture, the dynamics of its development (Table 1).

Table 1

Stages of service sector specialists' communicative culture formation

\begin{tabular}{|l|l|l|}
\hline \multicolumn{1}{|c|}{ Stages } & \multicolumn{1}{|c|}{ Components } & \multicolumn{1}{c|}{ Pedagogical conditions } \\
\hline 1. Awareness & Person-reflexive & $\begin{array}{l}\text { Orientation of the process of communicative } \\
\text { culture formation to the development of the } \\
\text { personality of future service sector specialists }\end{array}$ \\
\hline 2. Cognition & $\begin{array}{l}\text { Epistemological- } \\
\text { cognitive }\end{array}$ & $\begin{array}{l}\text { Introduction of 'Fundamentals of the service } \\
\text { sector specialists' communicative culture" } \\
\text { special course }\end{array}$ \\
\hline 3. Actualization & $\begin{array}{l}\text { Operational- } \\
\text { technological }\end{array}$ & $\begin{array}{l}\text { Developmentandapplicationofaholisticme } \\
\text { thodologytoformservicesectorspecialists' } \\
\text { communicative culture at vocational school }\end{array}$ \\
\hline 4. Adaptation & $\begin{array}{l}\text { Professionally- } \\
\text { adaptive }\end{array}$ & $\begin{array}{l}\text { Purposeful inclusion of communicative } \\
\text { competences in the educational and } \\
\text { production activities of future specialists in } \\
\text { the sphere of service }\end{array}$ \\
\hline
\end{tabular}


The stage of awareness is aimed at forming students' clear understanding of communicative culture as a marker of their professionalism, value attitude towards communication, as well as developing motivation to improve their own communicative culture, the ability to self-assessment and self-regulation in interpersonal communicative interaction. At the stage of cognition there is an accumulation of students' vocational and communicative experience in the form of knowledge of norms and rules. It is aimed at theoretical mastering of ways of establishing an interpersonal contact, adequate assessment of a person in a certain communicative situation, productive interaction in the professional field, etc. The most effective at these two stages of communicative culture formation is the use of cognitive methods (self-study, heuristic conversation, explanatory-illustrative, reproductive, problem ones), which, transmitting teaching from a passive to an active state, encourage students to productive educational and cognitive activity.

The pedagogical task of the actualization stage is aimed at developing professional communication skills as a system of internal means of communicative actions regulation based on the combination of closely related common goals of theoretical communicative training and the practical implementation of theoretical provisions in professional activities. Training methods such as simulation games, modeling and method of operational actions are basic at this stage; due to them the learning process acquires a dialogic, interactive nature.

The stage of adaptation is subject to the improvement of the developed communicative competencies while production training and production practice in service sector institutions. It concentrates the content of all previous stages of forming the service sector specialists' communicative culture, and should reflect the expected result of the methodology. Thereby, a great importance at this stage is given to the methods of control (observation, testing, self-evaluation, expert evaluation), which let us identify the students' communicative potential and the dynamics of their development, their attitude to improving their own professional and communicative qualities, as well as determine the level of self-training future service sector specialists.

The contemporary pedagogical technologies whose application will great lying rich the process of training reflect the scientific approach to designing a logically structured system of pedagogical interaction to guarantee the achievement of planned results in forming the future service sector specialists' communicative culture. Person-oriented technologies will 


\section{Formation of future service sector specialists' communicative culture during...}

help to reveal the communicative potential of vocational school students, to increase their motivation to improve their professional and communicative qualities. The technology of collective mental activity promotes the development of active listening skills, constructive interpersonal communication, and the establishment of feedback during communication. With the help of context learning technologies students are included in the professional context, taking into account its communicative and social-role features in accordance with the specifics of the profession. It contributes to the development of all four components of communicative culture. The transformation of the communicative knowledge of the future service sector specialist into the professional communication skills is carried out while applying the project technology. To make the cognitive activity of future service sector specialists active while forming their communicative culture is to provide information and communication technologies that raise the students' interest in work with educational and production information and help to apply acquired communication skills in practice. The elements of the technology for communicative culture formation by means of theater pedagogy will promote the development of creative abilities and reflexive thinking.

\section{Research results}

The ascertaining experiment allowed the authors to determine the actual state of formation of the future service sector specialists' communicative culture at vocational schools (Fig. 2). The analysis of working curricula for training skilled service sector workers revealed the pedagogical potential of general educational, general professional, professional theoretical subjects and vocational training for students' communicative culture formation, however, while observing the class activities, the manifestation of students' individual characteristics in communicative activities, their level of communication and readiness for professional communication, the influence of the teacher's personality on students' communicative qualities formation we stated that the teaching staff do not take into account this component of training. This is due to their lack of awareness with the task of communicative culture formation, its structure and stages of development. Consequently, VET uses predominantly traditional forms and methods of teaching that do not facilitate the establishment of a subject-subject pedagogical interaction, do not provide proper communicative activities while training future service sector specialists. 


\section{Rudenko Larisa, Lytvyn Andriy}

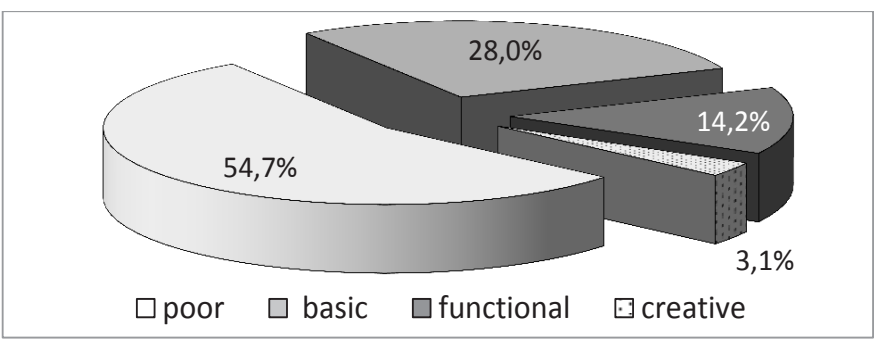

Fig. 2. Distribution of students according to the levels of formation of service sector specialists' communicative culture at vocational schools

The ascertaining study showed that $54.7 \%$ of future service sector specialists have a poor level of communicative culture, $28.0 \%$ are at the basic level, $14.2 \%$ are at the functional level and only $3.1 \%$ of the respondents are at the creative level. This gives grounds for the conclusion about the necessity to introduce a set of measures to improve this component of the future service sector specialists' training.

The formative experiment was aimed at testing the pedagogical conditions and methodology of future service sector specialists' communicative culture formation developed according to our model. The formation of person-reflexive, epistemological-cognitive, operational-technological, and professional-adaptive components of the future service sector specialists' communicative culture according to value, cognitive, activity and adaptive criteria was checked out. The study was conducted with a representative sample of 208 students in the experimental group (EG) and 204 in the control group (CG). The obtained results give grounds for stating that the EG has a higher and more predictable level of communicative culture. The level of the communicative culture of the students in vocational schools of the service sector, who were taught according to our methodology, is also significantly higher by all the criteria. The students of the EG are on the functional level on average, and the students of the CG are on the verge of the poor and basic levels of communicative culture. The generalized data on the study of the formation of all the components of the students' communicative culture (Fig. 3) indicate a low percentage of students (EG) with the poor level, as well as an insignificant number of them with the basic level of communicative culture. 


\section{Formation of future service sector specialists' communicative culture during...}

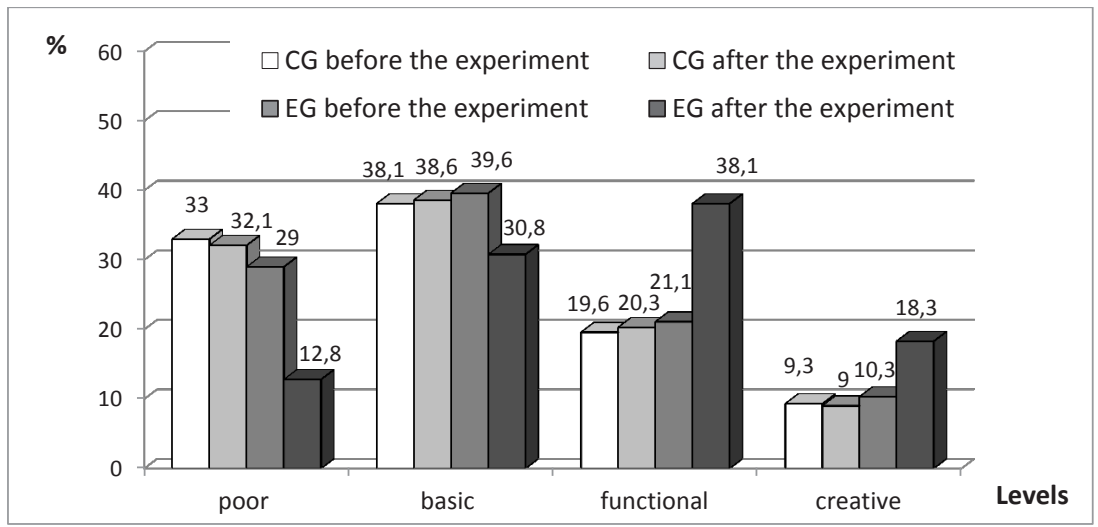

Fig. 3. Distribution of students in EG and CG according to the levels of communicative culture formation

For a comprehensive measurement of the dynamics of the communicative culture formation, factor-criterial qualimetry of educational institutions according to pedagogical conditions was used (Fig. 4) (Lytvyn, A. V. \& Rudenko, L. A., 2016, pp. 36). The growth of the level of the formation of the communicative culture of the future service sector specialists in the pilot vocational schools was most influenced by the content and technological factors that affected the positive dynamics of the motivational and adaptive factors of the communicative culture formation.

According to the expert assessment of the significance of the components of the pedagogical conditions for the formation of the communicative culture of future service sector specialists, the first place is taken by the introduction of the "Fundamentals of service sector specialists" communicative culture" special course; followed by the use of the author's methodology of communicative culture formation. The purposeful inclusion of communicative competences in the training activities of future service sector specialists and the orientation of the process of communicative culture formation to the personality's development occupies the third and fourth positions respectively in the hierarchy of pedagogical conditions for the formation of the students' communicative culture at the vocational schools of service sector. The coherence of the group assessment of the importance of 
Rudenko Larisa, Lytvyn Andriy

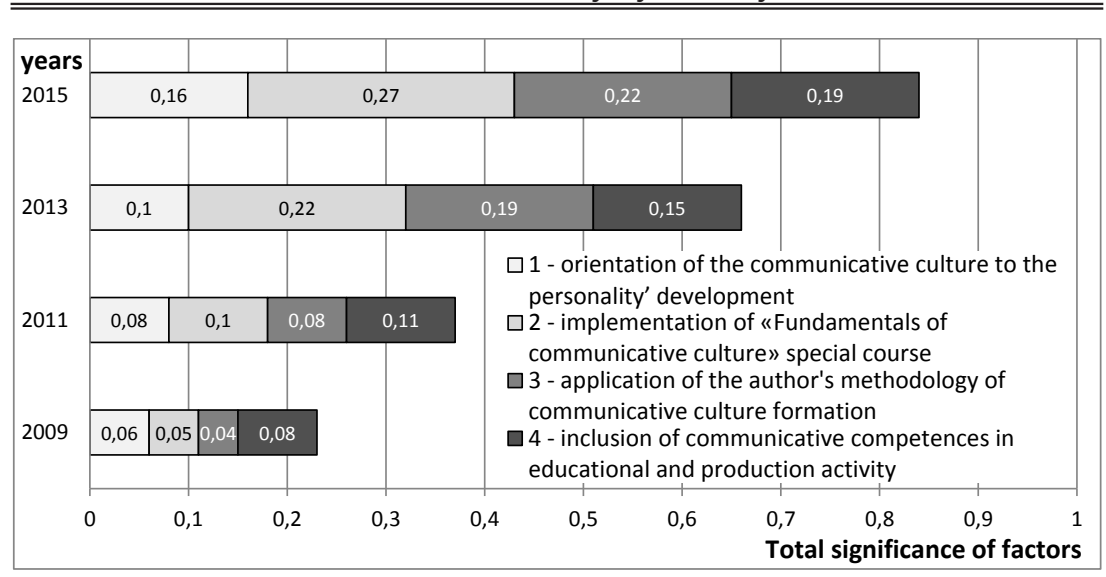

\section{Fig. 4. Dynamics of forming communicative culture of future service sector specialists at pilot vocational schools}

each pedagogical condition for increasing the efficiency of the educational process at vocational school is 0.77 .

The analysis of the data obtained during the research allows claiming that during the experiment there were systemic changes in the educational process; the level of communicative culture and vocational training of the vocational school leavers was increased. All the experimental results are generalized and statistically processed, that ensures their reliability. The results of the formative stage of the pedagogical research indicate a significant improvement in the quality of training of service sector qualified specialists due to the introduction of a system of communicative culture formation at vocational school.

\section{Conclusions}

1.Professional functions of service sector specialists are realized in communicative activities; the communicative culture plays the leading role in it. According to the philosophical, cultural, psychological and pedagogical essence of communicative culture in the context of service sector specialists' training and taking into account the specifics of their professional activity, the main methodological approaches to communicative culture formation are: cultural, axiological, person-oriented, synergistic, activity and competence ones. 


\section{Formation of future service sector specialists' communicative culture during...}

2. The structure of the service sector specialists' communicative culture covers four components: person-reflexive, epistemological-cognitive, operational-technological and professional-adaptive ones. During the training at vocational schools these components become person-oriented and are aimed at solving the problems of training, education and development of competent specialists.

3. The state of the formation of service sector specialists' communicative culture at vocational schools does not fully meet the requirements of the society for skilled workers in the service sector. This requires the development of the system of service sector specialists' communicative culture formation, the introduction of a set of measures in order to improve this component of vocational training.

4. According to the methodological approaches and taking into account the formulated patterns and specific principles, the authors distinguish the pedagogical conditions for the service sector specialists' communicative culture formation. The analysis of their implementation by means of factor-qualitative qualimetry of educational institutions shows that the effectiveness of this process in the pilot vocational schools is most influenced by the content and technological factors.

5. As it is demonstrated by testing, the model allows revealing the interdependence of the components of the communicative culture and, on this basis, determining the stages of its formation, providing the interactivity of training, effective feedback in pedagogical interaction, predicting the results of professional and communicative training of future service sector specialists.

6. The methodology of communicative culture formation is aimed at providing students with professionally meaningful communicative competences, promoting their personal development and increasing their opportunities for adaptation and self-realization in professional activities.

7. The prepared and implemented scientific and methodological support for the formation of the communicative culture of future service sector specialists at the vocational schools contains "Fundamentals of communicative culture" special course and "Methodical principles of service sector specialists' communicative culture formation" manual. Their implementation into the educational process of vocational schools proved their expediency for service sector specialists' training for professional communication activities. 


\section{References:}

1. Ananieva T. N., Butkevich M. N., \& Baghdasarian V. E. (Ed.). (2008). Conceptual and methodological aspects of the formation of serviceology - a science of synergetic type. Moscow: Sobranie.

2. Lytvyn, A. V. \& Rudenko, L. A. (2016). Checking the effectiveness of pedagogical conditions in scientific research. In: Harmonious personal development problem in relation to specificity of modern education and socialization processes : peer-reviewed materials digest (collective monograph) published following the results of the CXXXI International Research and Practice Conference and III stage of the Championship in Psychology and Educational sciences (London, Oct 5-11, 2016). (pp. 34-37). London: IASHE.

3. Rudenko L. (2014a). Epistemological aspect of the communicative culture of specialists. In: Influence of social and humanitarian subjects on the formation of future specialists' professional qualities: Proceedings of the round table; 2014 Ju 12; Lviv. (pp. 13-14). Lviv: Educational and Methodological Center for Vocational Education in Lviv region.

4. Rudenko L. (2015). Formation of communicative culture of future service sector specialists at vocational schools: Monograph. Lviv: Pyramid.

5. Rudenko L. (2014b). Informational and technological aspect of the communicative culture of service sector specialists. In: V. O. Radkevych (ed). Scientific and methodological provision of vocational education and training: Proceedings of the Reporting scientific and practical conference; 2014 Mar 24-25; Kyiv. (Vol. 1., pp. 160-163). Kyiv: Institute of VET at National Pedagogy Academy of Ukraine.

6. Rudenko L. (2013). Personality-reflective components of professionals' communicative culture in service sector. In: Forming and Qualitative Development of Modern Educational Systems / International Academy of Science and Higher Education. (Vol. LXIV, pp. 89-91). London: IASHE.

7. Rudenko L. (2016). Professional-adaptive component of the communicative culture of service sector specialists. In: Problems of modern philology: linguistics, literary studies, \& linguistic education: Collected works devoted to the 25th anniversary of the department of philological disciplines. (Iss. 9, pp. 76-84). Poltava: V. H. KorolenkoNationalPedagogicalUniversity of Poltava.

8. Rudenko L. (2012). Structural components of the communicative culture of service sector professionals. Pedagogical Sciences, 3 (56), 49-55.

9. Rudenko L. A. \& Lytvyn A. V. (2015). Historical aspects of professional training of specialists in the sphere of services. In: Topical issues of the history of science and technology: Proceedings of the 14th All-Ukrainian scientific conference; 2015 Oct 8-10; Lviv. (pp. 363-366). Kiev; Lviv: Center for Study of Museums of National Academy of Sciences of Ukraine, UTOPIK.

10. Udaltsova. M. V. \& Averchenk L. K. (2002). Service Study. Man and his needs: Textbook. Novosibirsk: Sibirskoe Soglashenie. 